\title{
Challenges in Developing Engineering Class Design at Middle Classroom to Improve Science,Technology, Engineering, and Mathematics (STEM) Education
}

\author{
I. Kaniawati, I. R Suwarma, L. Hasanah \\ Physics Education Department \\ School of Postgraduates Studies, UPI \\ Bandung, Indonesia \\ idakaniawati@upi.edu,rahmai@ymail.com
}

\author{
N. Y Rustaman, E. Nurlaelah \\ Biology, Mathematics Education Department \\ School of Postgraduate Studies, UPI \\ Bandung, Indonesia
}

\begin{abstract}
In this paper, we discuss challenges in designing engineering class that was conducted in a middle school to improve STEM education in Indonesia. Engineering class design was implemented in several schools in US to embed STEM education into school curriculum that emphasized on engineering practice. However, the class design is newly introduced in Indonesia. In fact, the education system differences become a crucial challenge. The class design was created through STEM professional development program, where seven teachers from Muhammadiyah 8 Secondary School in Bandung are involved in it. The class designing method was initiated by giving STEM education knowledge review to improve teacher's knowledge and perception. Furthermore, teachers were divided into two groups to analyze the contents in different level, and then they created big themes that cover several concepts in the contents. Finally, they plan students' STEM based project in a worksheet format that adapted engineering process design. The challenges were analyzed using 3Ps instrument that adopted from Bybee (2013). The result implied they meet challenges in designing the class when they decided the STEM activity purpose, program, and practice, that reflect on time consuming, number of participant, activity location, products, occurred problems, and attained agreement among participant.
\end{abstract}

Keywords-Engineering class, STEM Education

\section{INTRODUCTION}

United State government realize the lack of scientist and engineer because of the interest decrease in science, mathematics, engineering and technology field that impact on the interest decrease in these careers [1]. To solve these problems, government emphasizes STEM improvement in education. It was suggested that government should take with respect for improving leadership and coordination [1]. Moreover, standards, assessment, teachers, technology education, and schools become crucial targets to be developed. It concluded that to meet the need for STEM-capable citizenry and future STEM expert; the Nation must focus on two complementary goals. First, they should prepare all students, including the girls and minority, and inspire all students to learn STEM. Second, they should promote better leadership with a coherent vision with careful oversight of goals and outcomes. Therefore, federal government started to improve STEM education by releasing new science standard, Next Generation Science Standard (NGSS) on 2013[2]. Recently, ACT evaluate STEM education development, they reported that the percentage of students' interest in STEM has increase slightly over past five years [3]. The biggest increase were in Engineering and Technology area, especially mechanicalengineering area. These results showed that United State showed a success in promoting STEM education program. This fact triggers us to study about STEM education implementation strategy in U.S.

The successes of STEM education implementation in U.S haven't been seen in Indonesia. The first implementation in 2013 faced challenges, especially in integrating Engineering (E) and Technology (T) in science learning [4,5]. The difficulty arouse from limited experience to serve in STEM learning classroom. Reflect on implementation evaluation results, we develop engineering class design that adapted from Columbia Academy STEM program in Minnesota. We designed engineering class as an after school activity for middle school students. We grouped students into two different role-play; as supplier and producer, while the teacher act as client. In Indonesia the design is new and we have different education system with United State. Therefore we hypnotize that there will be many challenges occurs in adapting these design. This study focused on analysing the challenges in developing engineering class design process based on teachers' perception toward time, participant, location, products, problems, and agreement [5].

\section{METHOD}

\section{A. Research sample and professional development method}

The development processes were conducted during teacher training activities. The activity was part of professional development $(\mathrm{PD})$ program that organizes once a year. The first PD program was conducted in 2013; it aimed to introduce STEM education. The second PD was conducted on July 2015 that targeted to refresh teacher perception and repair the implementation method and strategy. Seven STEM teachers involved in it. Firstly, they were given STEM education review in other countries to refresh their perception of STEM 
education. Second, they were asked to analyze curriculum content. They listed the content of science, mathematics, and computer technology courses refer to 2006 Indonesian national curriculum. Third, they were asked to pick big topic of project that can covers content of each courses. They should think systemic to get the idea. Fourth, they were asked to create students guidance in conducting the project. Finally they were asked to arrange recruitment and learning schedule for one semester.

\section{B. Engineering class design}

The class was designed refer to Columbia Academy, a middle school in Minnesota. We designed class of 20 students that grouped into 2 groups of supplier and 4 groups of engineer. It conducted as out-of-school activity school program, which should be chosen based on students' interest. They were grouped based on their dominant intelligences profile using Multiple Intelligences Inventory (MII) ${ }^{7}$. The program served for seven and eight grade students, so we designed two engineering classes. The class started in the beginning of August 2015. It initiated with recruitment process in one week. There will be eighteen-class meeting, consisted of three projects for each class. Steps in conducting the learning are: 1) deliver the problem based on the topic of project, 2) divide students' role-plays, 3) encourage and guide students to create a project proposal, 4) assess students' proposal, 5) guide students in conducting the project, and 6) assess project result. Furthermore, we embedded engineering processes design into student's activities; students were guide to identify the problems, to have brainstorming in-group, to design the solution, to construct the design, to test the product, to redesign the product, and finally share the solution.

\section{Instrument and data analysis}

In order to evaluate challenges in the developing processes, we create questionnaire to collect teachers' perspective toward three areas: purpose, program, and practice in using STEM context that refer to how long time is needed, who are participated, location of implementation, what kind of product that produce in development processes, what problems occur along the processes, and how the agreement among participant was attained. This questionnaire was developed based on Bybee [5] perception in STEM education program evaluation. The questionnaire consists of two domains for each area. In the purpose area, we evaluate domain: a) establishing goals for STEM activities, b) establishing priority of STEM goals in STEM activities. In the program area, the domains are: a) developing material for STEM, b) implementing the class. And in practice area the domains are: a) changing teaching strategy for STEM, b) adapting material that suitable for students, teachers, and school need. Data were collected at the end of professional development program. It was analyzed qualitatively.

\section{RESULTS AND DISCUSSIONS}

\section{A. Differentiation method of engineering class design}

Implementation of STEM education in Indonesia was started on 2013. It has been conducting since November 2013 at a private junior high school in Bandung West Java Indonesia. Selected school has vision to improve student achievement in science, technology, engineering and mathematics. The principal wants students to be literate in STEM, to create better human resources in developing the country, to improve school quality, and to have better achievement in science and technology. Facing limitation of STEM knowledge, college collaboration, and school curriculum policy, it was decided to use other methods of implementation for the next school term semester. Project Based Learning (PBL) was taken as an approach of implementation in engineering class.

Engineering class design was built to improve STEM education that targeted to increase students' creativity, intelligences, and problem solving skill. The design was adapted from Columbia Academy in Minnesota. However, we have different scheme of implementation. They design the class as a regular subject twice a week, while we design it as a class in out of school activity program. We design the activity based on the attained concept on science, mathematics, and computer technology contents. It aims to improve students' concept mastery besides creativity, intelligences, and problem solving skills.

\section{B. Project theme in engineering class design}

TABLE 1. List of projects theme in engineering class design

\begin{tabular}{cc}
\hline \multicolumn{2}{c}{ List of Projects Theme } \\
\hline $7^{\text {th }}$ Grade & $8^{\text {th }}$ Grade \\
Dispenser Prototype & Healthy “Cilok" \\
The Earth Fever & Lung Breathing \\
Automatic Wind Blower & Hearth Work \\
\hline
\end{tabular}

TABLE 2. List of covered contents in science, mathematics, and computer technology subject in 2006 National Curriculum

\begin{tabular}{|c|c|c|}
\hline $\begin{array}{l}\text { Science } \\
\text { S.7.1. }\end{array}$ & $\begin{array}{c}\text { Mathematics } \\
\text { M.7.1 }\end{array}$ & $\begin{array}{c}\text { Computer } \\
\text { Technology } \\
\text { CT.7.1 }\end{array}$ \\
\hline $\begin{array}{ll}\text { a. } & \text { metal expansion } \\
\text { b. heat } \\
\text { c. temperature changes } \\
\text { d. heat transfer } \\
\text { e. compound } \\
\text { f. density } \\
\text { g. chemical properties } \\
\text { h. physics changes } \\
\text { i. chemical changes } \\
\text { j. } & \text { chemical reaction }\end{array}$ & $\begin{array}{ll}\text { a. } & \begin{array}{l}\text { counting } \\
\text { operation }\end{array} \\
\text { b. } & \begin{array}{l}\text { arithmetic } \\
\text { social }\end{array}\end{array}$ & $\begin{array}{l}\text { a. use of } \\
\text { computer }\end{array}$ \\
\hline S.8.1 & M.8.1 & CT.8.1 \\
\hline
\end{tabular}




\begin{tabular}{|c|c|c|}
\hline $\begin{array}{ll}\text { a. } & \text { digestive systems } \\
\text { b. } & \text { chemical materials } \\
& \text { in food } \\
\text { c. } & \text { respiration systems } \\
\text { d. } & \text { particle }\end{array}$ & $\begin{array}{ll}\text { e. } & \text { counting } \\
& \text { operation } \\
\text { f. } & \text { comparisons } \\
\text { g. } & \text { linear } \\
& \text { equation } \\
& \text { system of } \\
& \text { two variable }\end{array}$ & $\begin{array}{ll}\text { a. } & \text { power point } \\
\text { b. } & \text { excel }\end{array}$ \\
\hline
\end{tabular}

S.7.1 $=$ Science subject for seventh grade in first semester term $\mathrm{a}, \mathrm{b}, \mathrm{c}, \ldots=$ covered content

During the professional development program, teachers imply that there are some contents of mathematics, science, and computer technology that could be integrated conceptually. They built bridging theme to connect and correlate the concept in the content. They listed the covered contents in 2006 national curriculum, and then decided the project theme (Table 1). The covered contents that related to the projects theme were shown in Table 2.

In general, the purpose of each topic is to improve understanding concept of science, mathematics, and computer technology contextually through an active learning. For instance, the 'dispenser prototype' topic leads students to use heat concept in creating the prototype. It also cover concept: heat transfer (S.7.1a), temperature changes (S.7.1b), density (S.7.1c), arithmetic social (M.7.2), counting operation (M.7.1), and the use of computer (CT.7.1). Other sample describes on 'healthy Cilok' topic that covers contents of digestive systems, chemical materials in food, counting operation, comparison, power point, and excel.

\section{Challenges evaluation results}

The process on developing class design evaluated using 3PS evaluation rubric that adapted from Bybee [6]. Teachers who followed the development process are experience STEM teacher in the school sample. They followed STEM program implementation in the school for almost one year. However, they face challenges in the first implementation, thus we create new class design to deal with the challenges. The development processes was initiated by professional development program on STEM education. Teachers were given brief review of STEM education implementation in other country to refresh and improve their perspective. Based on their perspective, we guide them to create a topic for students' projects, and put them into a workbook.

Challenges on the development process were identified on time, participants, location, products, problems, and agreement of teachers. Teachers' perceptions toward these challenges were illustrated on Table 3 .

Table 3. Teachers' perceptions toward engineering class development processes challenges

\begin{tabular}{|c|c|c|c|c|c|c|}
\hline Dimension & Time & Participants & Location & Products & Problems/issues & Agreement \\
\hline \multicolumn{7}{|c|}{ Purpose } \\
\hline $\begin{array}{l}\text { Establishing } \\
\text { goals for } \\
\text { Engineering } \\
\text { Class }\end{array}$ & $\begin{array}{l}80 \% \\
\text { chose: } \\
\text { it need } \\
\text { more than } \\
\text { one hour }\end{array}$ & $\begin{array}{l}100 \% \text { chose } \\
\text { Engage fair } \\
\text { (not much) } \\
\text { colleagues, } \\
\text { relevant } \\
\text { community } \\
\text { and students }\end{array}$ & $\begin{array}{l}70 \% \text { chose } \\
\text { It conducts in the } \\
\text { location where } \\
\text { easy to be } \\
\text { accessed by } \\
\text { participants }\end{array}$ & $\begin{array}{l}70 \% \text { choose: } \\
\text { It producing } \\
\text { unique materials } \\
\text { that needed by } \\
\text { teacher, schools } \\
\text { and students }\end{array}$ & $\begin{array}{l}80 \% \text { chose: } \\
\text { The problem related } \\
\text { to: students, } \\
\text { teachers, and } \\
\text { learning materials }\end{array}$ & $\begin{array}{l}60 \% \text { chose: } \\
\text { There is good } \\
\text { communication among } \\
\text { participant so that the } \\
\text { agreement did not take } \\
\text { a lot of time and get } \\
\text { fine quality }\end{array}$ \\
\hline $\begin{array}{l}\text { Establishing } \\
\text { priorities for } \\
\text { STEM goals in } \\
\text { Engineering } \\
\text { Class activities }\end{array}$ & $\begin{array}{l}80 \% \\
\text { chose: } \\
\text { it need } \\
\text { more than } \\
\text { one hour }\end{array}$ & $\begin{array}{l}100 \% \text { chose } \\
\text { Engage fair } \\
\text { (not much) } \\
\text { colleagues, } \\
\text { relevant } \\
\text { community } \\
\text { and students }\end{array}$ & $\begin{array}{l}70 \% \text { chose } \\
\text { It conducts in the } \\
\text { location where } \\
\text { easy to be } \\
\text { accessed by } \\
\text { participants }\end{array}$ & $\begin{array}{l}70 \% \text { choose: } \\
\text { It producing } \\
\text { unique materials } \\
\text { that needed by } \\
\text { teacher, schools } \\
\text { and students }\end{array}$ & $\begin{array}{l}80 \% \text { chose: } \\
\text { The problem related } \\
\text { to: students, } \\
\text { teachers, and } \\
\text { learning materials }\end{array}$ & $\begin{array}{l}60 \% \text { chose: } \\
\text { There is good } \\
\text { communication among } \\
\text { participant so that the } \\
\text { agreement did not take } \\
\text { a lot of time and get } \\
\text { fine quality }\end{array}$ \\
\hline \multicolumn{7}{|c|}{ Program } \\
\hline $\begin{array}{l}\text { Developing } \\
\text { material or } \\
\text { adopting a } \\
\text { program for } \\
\text { Engineering } \\
\text { Class }\end{array}$ & $\begin{array}{l}80 \% \\
\text { chose: } \\
\text { it need } \\
\text { more than } \\
\text { one week }\end{array}$ & $\begin{array}{l}100 \% \text { chose } \\
\text { Engage fair } \\
\text { (not much) } \\
\text { colleagues, } \\
\text { relevant } \\
\text { community } \\
\text { and students }\end{array}$ & $\begin{array}{l}70 \% \text { chose } \\
\text { It conducts in the } \\
\text { location where } \\
\text { easy to be } \\
\text { accessed by } \\
\text { participants }\end{array}$ & $\begin{array}{l}70 \% \text { choose: } \\
\text { The products are } \\
\text { related to civic } \\
\text { phenomena } \\
\text { solutions that } \\
\text { connected to } \\
\text { STEM }\end{array}$ & $\begin{array}{l}80 \% \text { chose: } \\
\text { The problem related } \\
\text { to: students, } \\
\text { teachers, and } \\
\text { learning materials }\end{array}$ & $\begin{array}{l}60 \% \text { chose: } \\
\text { There is good } \\
\text { communication among } \\
\text { participant so that the } \\
\text { agreement did not take } \\
\text { a lot of time and get } \\
\text { fine quality }\end{array}$ \\
\hline $\begin{array}{l}\text { Implementing } \\
\text { the } \\
\text { Engineering } \\
\text { Class program }\end{array}$ & $\begin{array}{l}80 \% \\
\text { chose: } \\
\text { it need } \\
\text { more than } \\
\text { one month }\end{array}$ & $\begin{array}{l}100 \% \text { chose } \\
\text { Engage fair } \\
\text { (not much) } \\
\text { colleagues, } \\
\text { relevant } \\
\text { community }\end{array}$ & $\begin{array}{l}70 \% \text { chose } \\
\text { It conducts in the } \\
\text { location where } \\
\text { easy to be } \\
\text { accessed by } \\
\text { participants }\end{array}$ & $\begin{array}{l}70 \% \text { choose: } \\
\text { The products are } \\
\text { related to civic } \\
\text { phenomena } \\
\text { solutions that } \\
\text { connected to }\end{array}$ & $\begin{array}{l}80 \% \text { chose: } \\
\text { The problem related } \\
\text { to: students, } \\
\text { teachers, and } \\
\text { learning materials }\end{array}$ & $\begin{array}{l}60 \% \text { chose: } \\
\text { There is good } \\
\text { communication among } \\
\text { participant so that the } \\
\text { agreement did not take } \\
\text { a lot of time and get }\end{array}$ \\
\hline
\end{tabular}




\begin{tabular}{|c|c|c|c|c|c|c|}
\hline Dimension & Time & Participants & Location & Products & Problems/issues & Agreement \\
\hline & & and students & & STEM & & fine quality \\
\hline \multicolumn{7}{|c|}{ Practice } \\
\hline Dimension & Time & Participants & Location & Products & Problems/issues & Agreement \\
\hline $\begin{array}{l}\text { Changing } \\
\text { teaching } \\
\text { strategies for } \\
\text { STEM }\end{array}$ & $\begin{array}{l}80 \% \\
\text { chose: } \\
\text { it need } \\
\text { more than } \\
\text { one week }\end{array}$ & $\begin{array}{l}80 \% \text { chose } \\
\text { Engage fair } \\
\text { (not much) } \\
\text { colleagues, } \\
\text { relevant } \\
\text { community } \\
\text { and students }\end{array}$ & $\begin{array}{l}70 \% \text { chose } \\
\text { It conducts in the } \\
\text { location where } \\
\text { easy to be } \\
\text { accessed by } \\
\text { participants }\end{array}$ & $\begin{array}{l}70 \% \text { choose: } \\
\text { It producing better } \\
\text { teaching strategies } \\
\text { and stories in } \\
\text { STEM }\end{array}$ & $\begin{array}{l}80 \% \text { chose: } \\
\text { The problem related } \\
\text { to: students, } \\
\text { teachers, and } \\
\text { learning materials }\end{array}$ & $\begin{array}{l}60 \% \text { chose: } \\
\text { There is good } \\
\text { communication among } \\
\text { participant so that the } \\
\text { agreement did not take } \\
\text { a lot of time and get } \\
\text { fine quality }\end{array}$ \\
\hline $\begin{array}{l}\text { Adapting } \\
\text { materials to } \\
\text { unique needs } \\
\text { of teacher, } \\
\text { schools, and } \\
\text { students }\end{array}$ & $\begin{array}{l}80 \% \\
\text { chose: } \\
\text { it need } \\
\text { more than } \\
\text { one month }\end{array}$ & $\begin{array}{l}80 \% \text { chose } \\
\text { Engage fair } \\
\text { (not much) } \\
\text { colleagues, } \\
\text { relevant } \\
\text { community } \\
\text { and students }\end{array}$ & $\begin{array}{l}70 \% \text { chose } \\
\text { It conducts in the } \\
\text { location where } \\
\text { easy to be } \\
\text { accessed by } \\
\text { participants }\end{array}$ & $\begin{array}{l}70 \% \text { choose: } \\
\text { It producing better } \\
\text { teaching strategies } \\
\text { and stories in } \\
\text { STEM }\end{array}$ & $\begin{array}{l}80 \% \text { chose: } \\
\text { The problem related } \\
\text { to: students, } \\
\text { teachers, and } \\
\text { learning materials }\end{array}$ & $\begin{array}{l}60 \% \text { chose: } \\
\text { There is good } \\
\text { communication among } \\
\text { participant so that the } \\
\text { agreement did not take } \\
\text { a lot of time and get } \\
\text { fine quality }\end{array}$ \\
\hline
\end{tabular}

In general, teachers perceived that they faced challenges in time, participants, and problems in developing the engineering class. Most of them $(80 \%)$ thought that they need more time in establishing goals (purpose), developing and implementing materials (program), and changing and adapting learning processes (practice).

The time consuming in deciding the purpose of the class designed was affected by the STEM education implementation target to increase student's creativity, intelligences and problem solving skills. Therefore, teachers need more time to decide purpose, program, and practice of the projects theme. Student's creativity could be triggered with the power of questions [7], and the problem solving skills could be trained through problem-based instruction [8]. On the other hand, students have different dominant intelligences that should be considered [9]. Finally, they decided to use technology competition strategy in the practice to provide constructive environments where students can solve challenging complex open-ended problems with the guidance of adult mentors from STEM fields [10].

\section{CONCLUSION}

Overall, teachers develop adapted engineering class in different way to the adapted method in Colombia Academy, based on an analysis content in 2006 national curriculum. Therefore, they perceived that they faced some challenges in time, participants, and problems in developing the engineering class. Most of them (80\%) thought that they need more time in establishing goals (purpose), developing and implementing materials (program), and changing and adapting learning processes (practice). Thus, it needs further implementation evaluation toward the engineering class design impacts for both students and teachers.

\section{ACKNOWLEDGMENT}

We thank to Postgraduate Studies Indonesia University of Education (UPI) that supported us through their research grant.

\section{REFERENCES}

[1] PCAST. Report to the president: Prepare and inspire: K-12 education in science, technology, engineering, and math (STEM) for America's future, 2010. Retrieved at March 2013 from http://pcast.org/pcast-stemed-report

[2] NGSS, Next Generation Science Standards, Retrieved at March 2013 from www.ngss.org

[3] ACT, The national condition of STEM 2014. Retrieved at July 2014 from http//act.org.

[4] Suwarma Irma R, Kumano Yoshisuke, "First Implementation Of STEM Education Challenge in Indonesia", in STEM Education Center Seminar, University of Minnesota, unpublished.

[5] Suwarma Irma R, Kumano Yoshisuke, "First implementation of STEM education in Indonesia: teacher analysis result of STEM education and science \& math content in curriculum", in $38^{\text {th }}$ JSSE National Seminar proceeding, ISSN 2186-3636, 2014.

[6] Bybee. R. W. The case for STEM Education Challenges and Opportunity, Washington D.C, NSTA Press, 2013.

[7] Penick. J.E. Creativity and the value of questions, Chapter 8 in Yager. R.E(ed): STS as reform in science education, New York: SUNY Press, 1995.

[8] Alexandra Beatty, Rapporteur; Committee on Highly Successful Schools or Programs for K-12 STEM Education; National Research Council, 2011.

[9] Gardner, H. "Reflections on multiple intelligences", Phi Delta Kappan 77(3), 200-208, 1995.

[10] Katansky. D, "Bridging creativity and STEM crisis", ASQ advanceing STEM Agenda Conference, 2013. 